\title{
INDONESIAN STUDENTS' ERRORS IN THE USE OF DETERMINERS
}

\author{
Tyas Gita Atibrata
}

\begin{abstract}
This research attempts to investigate Indonesian students' errors in the use of determiners in their English writing. More specifically, it is an attempt to identify Gadjah Mada University English Department students' errors in the use of English determiners and classify them according to the types of determiners and the structural change of determiners. The results of the research shows that most of the incorrect use of the determiners was in the form of articles with 71 cases $(72.44 \%)$, followed by possessives 12 $(12.24 \%)$, demonstratives $10(10.20 \%)$, and quantifiers 5 cases $(5.10 \%)$. The results seem to suggest that the students had the greatest difficulty in the use of articles in writing in English. However, they did not seem to have difficulty in the use of demonstratives, possessives, and quantifiers. The incorrect use of determiners Icaused some structural alteration of the determiners. There are five types of stuructural alteration of determiners: addition, omission, misorder, misformation, and misuse. Most of them were omission with 29 (29.59\%). All of them were in the form of articles, followed by misformation with 28 cases $(28.57 \%)$, addition with 19 cases $(19.38 \%)$, misuse with 14 cases $(14.28 \%)$, and misordering with 8 cases $(8.16 \%)$. The results suggest that most of the students tend to omit the articles in their writing.
\end{abstract}

Keywords: Determiner, Errors, Alteration, Articles, Possessives, Demonstratives, Quantifiers,

\section{INTISARI}

Penelitian ini bertujuan untuk menganalisis kesalahan pemakaian determiner yang dilakukan oleh mahasiswa Indonesia yang terkandung dalam tulisan bahasa Inggris mereka. Secara lebih khusus, penelitian ini bertujuan untuk mengidentifikasi kesalahan pemakaian determiner oleh mahasiswa jurusan Sastra Inggris, Universitas Gadjah Mada dan mengklasifikasikan kesalahan-kesalahan tersebut berdasarkan jenis-jenis determiner dan perubahan struktur pada determiner. Hasil dari penelitian ini menunjukkan bahwa kesalahan pemakaian determiner paling banyak pada bentuk article dengan 71 kesalahan (72.44\%) diikuti oleh possessives 12 (12.24\%), demonstratives 10 (10.20\%), dan quantifiers 5 cases (5.10\%). Hasil ini menunjukkan bahwa para mahasiswa tersebut mempunyai kesulitan paling banyak dalam pemakaian article. Namun begitu, para mahasiswa tersebut sepertinya tidak memiliki kesulitan dalam pemakaian possessives, demonstratives, quantifiers. Kesalahan pemakaian determiner ini menyebabkan beberapa perubahan struktur dari determiner tersebut. Terdapat lima jenis perubahan struktur determiner: addition, omission, misorder, misformation, dan misuse. Perubahan paling banyak ialah omission dengan 29 $(29.59 \%)$ yang kesemuanya merupakan article, diikuti dengan misformation with 28 (28.57\%), addition $19(19.38 \%)$, misuse $14(14.28 \%)$, dan misordering 8 cases $(8.16 \%)$.

Kata Kunci: Determiner, Kesalahan, Perubahan, Articles, Possessives, Demonstratives, Quantifiers 


\section{INTRODUCTION}

When writing or speaking in English, we need to take into account a number of grammatical aspects. One such aspect is the use of determiners. Determiners play an important role in the construction of noun phrases because they modify the head nouns. Somehow people tend to be confused about what kind of determiners that they have to put in front of their nouns. As they study English, students of the English Department are expected to be able to use determiners correctly when speaking or writing in English. However, one can still find errors in the use of determiners in their English as illustrated in the examples below, taken from the pieces of writing of students of the English Department, Gadjah Mada University (see 1.4 below for more detail about the data source.)

(1) I hope my life in 2011 the better from before years

The definite article the is not used for showing comparison. However, in this clause the student tries to exprees a situation that might happen in the future. In this case, the article the is best substituted with the verb phrase will be since that verb phrase is used to denote something happen in the future. The correct version for the example above is

(2) I hope my life in 2011 will be better from before years

Another example of the errors in the use of determiners by the student is:

(3) Upon facing difficulties in life. People think of the way to avoid or solve that difficulties and make things more easier

The correct demonstrative to precede the noun difficulties is those since the demonstra- tive that is only used with a singular noun while difficulties is plural. The best substitution for the determiner that is those. Therefore, the correct version for the example above is:

(4) Upon facing difficulties in life. People think of the way to avoid or solve those difficulties and make things more easier

On the basis of such errors and considering the importance of determiners in the construction of noun phrase in English, this research attempts to investigate Indonesian students' error in the use of determiners in their English writing and classify them according to the types of determiners and structural changes of the determiners. This research uses syntax theory to analyze the wrong use of determiners. However, some cases also need pragmatics and semantics theories since choosing the right determiner to be used in a noun phrase are not only because of the syntax pattern of the noun phrase but also from the context of a clause or a paragraph where the determiners are included. This research only investigates the central determiners. According to Leech and Startvik, there are three types of determiners predeterminers, central determiners, and post determiners. This research will not going to discuss either the wrong use of pre-determiners or post-determiners that probably occur in the data source.

The sources of the data used in this research were taken from the students' writing final exam in General English. The examination was held in the year 2010. The students were in their first year. Most the data are in the form of noun phrases; however some are in the form of clauses and sentences in or- 
der to know the correct determiner to choose we should know the context meaning of the whole sentences.

\section{Determiners}

\section{Definition}

Leech and Startvik (1981: 225) state that determiners are words which specify the range of reference of a noun in various ways, e.g. by making it definite (the boy), indefinite (a boy), or by indicating quantity (many boys). It is also supported by Hornby (1982: 117), that a determiner may identify a person or thing, or two or more persons or things, as in this book, those pens, John's or my brother's car, etc. Furthermore, Hornby also states that a determiner may also indicate a quantity or amount (affirmatively or negatively), as in three/several/some/a few men; some/no/a little/not much water. According to Radford (1997: 295), a determiner is a word like a/the/this/that which is typically used to modify a noun, but which has no descriptive content of its own. Determiners can be used either pre-pronominally (i.e. in front of a noun that they modify) or pronominally (i.e. used on their own without a following noun)-cf. the two uses of that in I don't like that idea/ I don't like that. It is also added by Morley (2000: 51), who regards determiners as a functional, specifer element of structure in the nominal phrase, which may be expressed by a range of word subclasses (and by some phrases) which occur in abdominal position. Ba'dulu (2008: 15) also mentions that determiners are function words covering the articles, numerals, demonstratives, and possessive pronouns and they commonly occur with nouns to form noun phrases. From all of the explanations above, it can be con- cluded that the determiner are function words that occurs before a noun to modify, specify, and identify a noun in various ways, in order to form a noun phrase.

\section{Position}

As a function word, a determiner will not be found to stand on its own in a sentence. Since it does not have any semantic meaning, it is meant to fulfill a particular function and it is used together with a noun in a noun phrase in order to modify the noun. However, in forming a noun phrase a noun might not be accompanied only by a determiner as its dependent element. Leech and Startvik (1981: 251 ) states that a noun phrase consists of a noun as its head, a determiner (the, his, a, etc.) and one or more modifiers. Huddleston (1989: 227) also says that a noun as the head of a noun phrase takes a different range of dependents from other parts of speech. Most distinctively, it takes determiners and adjectives as pre-head modifiers. Morley (2000: 54) also says that a nominal phrase with a noun headword may typically be preceded and modified (pre-head modification or premodification) or determined by an article, a genitive phrase, a pronoun, an adjective (adjectival phrase or another noun (nominal phrase) and it may be followed and qualified (post-head modification or post-modification) by a prepositional phrase or subordinate clause, or in certain cases an adjective or nominal phrase. It can be said that the presence of a determiner will be found in a noun phrase preceding the head co-occuring with noun and other modifers that modify the head.

The determiners in a noun phrase always occur preceeding the head. The dia- 
gram below shows the position of determiners and modifiers in a noun phrase (Leech and Startvik, 1981: 251).

In this structure we can see that determiners are placed in initial position and come before the premodifiers.

In other words, it can be said that the determiners commonly precede a noun and it comes before a premodifier. Therefore it is usually placed in initial position.

\section{Types of Determiner}

Determiners are commonly co-occurring with nouns. However, they have different positions relative to one another. Quirk and Greenbaum (1973: 62) mention that there are predeterminers, determiners, and postdeterminer. Leech and Startvik (1981: 225) say that the determiners always precede the nouns they determine, but they have different positions relative to one another. The most important category is the central determiners, including articles. The central determiners may be preceded by predeterminers and/or followed by postdeterminers.
Huddleston (1989: 233) argues that an NP may contain up to three determiners: ideas has none, her ideas one, her many ideas or all her ideas is two, and all her many ideas is three. Where there is more than one, the order is fixed (cf. *many her ideas). Huddleston distinguishes three determiner position simply labelled I, II, and III which is similar to predeterminer (I), central determiner (II), post determiner (III).

However, there are some strict rules of what predeterminers can occur with what central determiners and what central determiners can occur with post determiner. Quirk and Greenbaum (1973: 63) say that the predeterminer all, both, half can occur only before demonstratives but since they are themselves quantifiers, they do not occur with the following 'quantitive' determiners: every, (n) either, each, some, any, no, enough. It is also supported by Huddleston (1989: 234) that All and both can occur only with II the; this, these, that, those, Poss $P$ (i), we, us; you (ii) or alone.

According to Huddleston such and exclamative what, that it occurs only with a or

Table 1. Types of Determiners According to Leech and Startvik (1981: 225)

\begin{tabular}{|c|c|c|c|}
\hline & PREDETERMINERS & CENTRAL DETERMINERS & POSTDETERMINERS \\
\hline a. & all, both, half & Articles: the, a (an), & Cardinal numerals: one, two, etc \\
\hline b. & double, twice, etc. & $\begin{array}{l}\text { Demonstratives: this, these, that, } \\
\text { those }\end{array}$ & Ordinal numerals: first, second, etc. \\
\hline c. & one-third, etc. & $\begin{array}{l}\text { Possessives: my, your, etc. and } \\
\text { genitives }\end{array}$ & General ordinals: next, last, other, etc. \\
\hline d. & what, such, etc. & $\begin{array}{l}\text { Quantifiers: some, any, no, ev- } \\
\text { ery, each, either, neither, enough, } \\
\text { much }\end{array}$ & $\begin{array}{l}\text { Quantifiers: many, few, little, several, } \\
\text { more, less, etc. }\end{array}$ \\
\hline e. & & $\begin{array}{l}\text { Wh-determiners: what(ever), } \\
\text { which(ever), whoever, whose }\end{array}$ & \\
\hline
\end{tabular}


alone. For example what/such a nuisance, what/such fine singing.

For postdeterminers, Quirk and Greenbaum (1973: 65) say that all ordinals (ordinal numerals and general ordinals) usually precede any cardinal number in the noun phrase, e.g.: The first three planes were American. The general ordinals, however, may be used freely before or after cardinals, according to the meaning required, e.g: His last two/ two last books were novels. Huddleston adds that the cardinal numerals like one, two, etc, occur after II (i), (ii), which, any, no, or alone, e.g.: the four sons, those three crooks, John's one mistakes, you two girls, which/any one article, no one man, five cats.

Huddleston also explains that the postdeterminer may occur after II (i) or alone: the many mistakes, those many crimes, her many attractive qualities, many people. Huddleston adds that much, in spite of its close semantic relationship to many, occurs only alone and hence is assigned position II.

\section{Forms and Functions}

In order to know what determiner can occur with what noun, first we have to identify the noun in terms of its plurality and countableness. Leech and Startvik (1981: 261) add that there are three classes of common nouns relevant to the choice of determiners: they are singular count nouns (such as bottle), plural count nouns (such as bottles), and mass noun (such as music). Proper nouns normally take no determiner. Hornby (1982: 118) also says that for the purpose of setting out the ways in which determiners are used (or not used) with nouns, the distinction between what are now often called 'countables' or 'count nouns' and 'uncountables' or 'mass nouns' is useful. Furthermore, Hornby adds that uncountable nouns can be used with or without determiners while countable nouns must have determiners.

\section{(A) Articles}

Articles are a subclass of determiners. There are two types of articles in English, the definite and indefinite (Leech and Startvik, 1981: 52). The form of definite article is the, while the indefinite articles are a or an. Leech and Startvik explain that when the definite article the is used, both the speaker and the hearer know what is being talked about. It is in contrast of using the indefinite article that the noun which is being talked about is not clearly defined or not unique. However, according to Morley (2000: 45) articles are used to mark specifity, generalization, or universality of reference to the entity denoted by the following noun.

\section{a. The definite article}

The definite article can be used in all classes of noun: singular countable nouns, plural countable nouns, and mass noun. Hornby (1982: 126) says that the definite article the may be used with countable nouns, singular and plural, and with uncountable nouns.

Leech and Startvik (1981: 54) state that the definite article is used in some certain conditions. For instance: when the noun is the only one that ever existed; the noun is followed by postmodifier, to represent a class or a kind of animals or things; the noun is a certain proper noun. Thompson and Martinett (1983: 4) add that the is used when the noun has been mentioned earlier; the noun is clearly defined or understood by all the members 
in conversation; to denote superlatives; when the noun is the names of ocean, seas, rivers, deserts, etc., with the names consisting of noun + of + noun; the noun is a musical instrument. Furthermore, Hornby (1982: 127) adds that the is also used to represent a class or a kind of animals or things.

However, according to Thompson and Martinett (1983: 5) the definite article does not appear in certain conditions such as before names of places (continents, countries, states islands, towns, streets, squares, building etc.) and names of persons, after a noun in the possessive case, or a possessive adjective, before names of meals, before noun home, and before a noun which denotes a building.

\section{b. The Indefinite Article}

The form of the indefinite article is a or an. The form of the indefinite article depends on the initial letter of the noun that comes after the article. Thompson and Martinet (1983: 6) explain that the form $a$ is used before words begins with a consonant or a vowel sounding like a consonant. e.g.: a man, a table, etc. In the contrary, the form an is used before words begin with a vowel $(a, i, u, e, o)$ or begins with a mute $h$. According to Hornby (1982: 125) the indefinite article $a$ or an is used when to say something at the first time; to take an example of a class; with a numeral expression; following exclamatory what; to make a meaning of each and every. Thompson and Martinett (1983: 1) say that the indefinite article is used with few and little and with a noun complement.

\section{(B) Demonstratives}

Demonstratives are a kind of determiners that mark nouns in terms of plurality and dis- tant. Quirk and Greenbaum (1973: 107) propose the following table:

Table 2. Types of Demonstratives According to Quirk and Greenbaum

\begin{tabular}{lll}
\hline & singular & plural \\
\hline 'near' reference & this & these \\
'distant' reference & that & those \\
\hline
\end{tabular}

The forms of demonstratives are this, that, these, and those. This and that occur with singular nouns while these and those occur with plural nouns. However, this and these express a near reference while that and those express a distant reference. Furthermore, Murphy (1997: 154) says that this and these means here, while that and those means there. Below are some examples:

(9) I like these pictures (which are near me) better than those pictures (over there on the far side).

(10)I like this idea (that you've mentioned) better than that silly idea (the one that you wrote to me about last year).

source: Murphy (1997: 154)

\section{(C) Possessives}

There are two kinds of possessives. Quirk and Greenbaum (1973: 105) mention that the possessives belong to two series: the attributives (my, your, etc.) and the nominals (mine, yours, etc.). It is also supported by Hornby (1982: 121), who says that the possessive adjectives are my, your, his, her, its, etc. while the possessive pronouns are mine, ours, yours, his, hers, its, etc. However, the kind of possessive that belongs to the class of determiners is the attributive or possessive adjective one. 
Thompson and Martinett (1983: 37) state that possessive adjectives in English refer to the possessor and not to the thing possessed. Everything that a man or boy possess is his thing; everything that a woman or a girl possesses is her thing. The forms of adjectives are: or group singly rather than look at them all together. The 'distributive' meaning of every shows in the use of singular noun (teacher), singular verb (studies), and also singular possessive (his). It is also supported by Murphy (1997: 166) that says every is used with singular noun and singular verb. However, Ev-

Table 3. Types of Possessive According to Hornby (1982: 118)

\begin{tabular}{|c|c|c|c|c|c|}
\hline & First Person & Second Person & Third Person & & \\
\hline & Singular & Plural & $\begin{array}{l}\text { Singular } \\
\text { and } \\
\text { Plural }\end{array}$ & Singular & Plural \\
\hline Possessive & my & our & your & his, her, its & their \\
\hline
\end{tabular}

\section{(D) Quantifiers}

Quantifiers are determiners which denote the quantity of the nouns they modify. Leech and Startvik (1981: 48) regard quantifiers as amount words which tell the amount of the nouns they modify. In central determiners, the forms of quantifiers are some; any; no; every; each; either; neither; enough; much.

\section{a. Some and Any}

Usually some is parallel with any. Thompson and Martinett (1983: 24) say that some and any mean 'a certain number or amount'. They are used before plural or uncountable nouns. Some is usually used in affirmative sentence; with questions when the answer 'yes' is expected; in offers and requests while any is usually used in negative sentence.

\section{b. No}

The determiner no is used with singular, plural, and mass noun. No is a determiner that used to express negative.

\section{c. Every}

Leech and Startvik call every as distributives, because it picks out member of a set ery is a determiner that seems to identify the noun as a sample that represents a class but somehow the use of every is similar like all. A part from this difference, every has the same meaning as all.

\section{d. Each}

Each is a determiner that the used is almost the same with every as Leech and Startvik (1981: 50) say that each is like every that it can be used when the set has only two members. It is also supported by Quirk and Greenbaum that each entails reference to two or more, and has single reference. Thus:

(11) There were two boys who called and I gave an apple to each

(12) *There were two boys who called and I gave an apple to every(body)

Furthermore, Quirk and Greenbaum explain that a meaning difference between each and every. Each refers to a single reference already specified whereas every does not. However, like every, each also occurs with singular noun and uses singular verb. 


\section{e. Either and Neither}

Either and neither are determiner that usually used in negative sentence as Leech and Startvik (1981: 254) say that either is used in negative sentences and interrogatives. Furthermore, Murphy (1997: 170) says that we use either / neither to talk about two things or people.

\section{f. Enough}

Hornby (1982: 123) states that this determiner is used with plural countable nouns and with uncountable nouns. Furthermore, Murphy (1992: 170) adds that enough is used when the amount of the noun is matched with the portion of you needed. It is neither less nor too much.

\section{g. Much}

Much is the only determiner that can only occur with uncountable noun. Quirk and Greenbaum (1973: 103) mention that that much co-occurs with non-count nouns. It is usually used in negative and interrogative sentence. It is a determiner that identify the noun in terms of its quantity. Hornby (2006: 961) says that much means a large amount of something.

\section{(E) Wh-determiners}

Wh-determiners are determiners that begin with wh as their two initial letters. There are whose, which (ever), what (ever). These determiners are sometimes also known as question words. According to Leech and Startvik (1981: 226) wh- determiners co-occur with all three classes of nouns (singular, plural, and mass noun).

According to Hornby (1982: 122) what is used in anything of non-personal. What refers to noun that is more general than which does.
Hornby says that which is selective and used when there is a limited choice, as in:

(13)What's the capital of Turkey?

(14)Which city is larger, Ankara or Istanbul?

The additional ever in the end of what means no matter what, while the additional in which means any one or any number of one group as in;

(15)She loves whatever her boyfriend does

(16) Take a card; whichever you want! However, the determiner whose reflects that the noun that is preceded belongs to other thing, as in: (17) Whose money did you borrow?

\section{Types of Determiner Errors}

According to the results of the research, there are 98 determiner errors were found. Most of them were articles with 71 cases (72.44\%), followed by possessives with 12 cases $(12.24 \%)$, demonstratives with 10 cases $(10.20 \%)$, and quantifiers with 5 cases $(5.10 \%)$. However, in this research no wh-determiners were found. Therefore, wh-determiners has 0 case with 0 percentage.

Table 5. above presents a summary of the research results. In addition to the classification of the errors according to the types of determiners, the errors are also classified according to the structural alteration of the determiners: addition, omission, misordering, misformation, and misuse.

The results seem to suggest that the students had the greatest difficulty in the use of articles in writing in English. They did not seem to have difficulty in the use of demonstratives, possessives, and quantifiers. In the 
Table 4. Distribution of Determiner Errors

\begin{tabular}{lcccccc}
\hline \multicolumn{1}{c}{ Determiners } & Addition & Omission & Misordering & Misformation & Misuse & Total \\
\hline Articles & $17(17.89 \%)$ & $29(29.59 \%)$ & $4(4.08 \%)$ & $15(15.30 \%)$ & $6(6.12 \%)$ & $71(72.44 \%)$ \\
Demonstratives & 0 & 0 & $3(3.06 \%)$ & $7(7.14 \%)$ & & $10(10.20 \%)$ \\
Possessives & $1(1.02 \%)$ & 0 & $1(1.02 \%)$ & $3(3.06 \%)$ & $7(7.14 \%)$ & $12(12.24 \%)$ \\
Quantifiers & $1(1.02 \%)$ & 0 & 0 & $3(3.06 \%)$ & $1(1.02 \%)$ & $5(5.10 \%)$ \\
\hline Total & $19(19.38 \%)$ & $29(29.59 \%)$ & $8(8.16 \%)$ & $28(28.57 \%)$ & $14(14.28 \%)$ & $98(100 \%)$ \\
\hline
\end{tabular}

following sections, both classifications will be presented and discussed more detail. The examples of the errors that are delivered may contain of another errors of another grammatical aspect. However, the researcher is not going to discuss nor to correct them.

\section{Errors according to the Types of De- terminers}

\subsection{Articles}

More than half of the errors in the use of determiners are in the form of articles. $71(72.44 \%)$ errors were found in the use of articles. $42(59.15 \%)$ of the errors were related with the use of the definite article and $29(40.84 \%)$ errors were related with the use of the indefinite article. From the result it can be assumed that the students of English Department students have difficulty in the use of article in general and the definite article in particular.

\subsubsection{The Indefinite Article}

The indefinite articles a/an are the determiners that are used with singular countable nouns (Hornby, 1982: 125). According to Huddleston (1989: 50) the indefinite article indicates that the description is not presented as defining. There are 29 errors found in the use of the indefinite article. Below are some of the examples of errors in the use of the indefinite article.

(18) Indonesian people give support, spirit, and motivation to Indonesian football player to be a champion although they hadn't been a champion (ART08-1)

The word champion is mentioned twice in this sentence. Therefore, the champion in the second mention should be preceded by the definite article the instead of the indefinite article $a$. The correct version for the example above is

(19) Indonesian people give support, spirit, and motivation to Indonesian football player to be a champion although they hadn't been the champion

\subsubsection{The Definite Article}

The definite article use is to indicate that what is expressed by the noun has been mentioned already and to refer back to it. (Hornby,) the may be used with countable nouns, singular and plural, and with uncountable nouns. Below are some examples of errors in the use of the definite articles

(20) He become most wanted by fans especially women (ART19-1) 
The definite article the is used in superlative form. Therefore, the respondent should add the in the phrase most wanted. The correct version is

(21) He become the most wanted by fans especially women (ART19-1)

From these various examples above, it can be seen that the students do not seem to understand fully the different functions of the definite and the indefinite article. They used the definite article when in fact the indefinite article was needed and vice versa.

\subsection{Demonstratives}

Demonstratives are a kind of determiners that mark nouns in terms of plurality and distance. Below are some examples of errors in the use of demonstratives.

(26) I beliefe that all people certainly can to face life this (DEM06-3)

Determiners always precede nouns. Leech and Startvik (1981:225) say that determiners always precede the noun they determine. However, in this example, the determiner this is used after the noun reality. Therefore the noun phrase is erroneous and should be in the order this reality.

(27) I beliefe that all people certainly can to face this life

\subsection{Possessives}

Thompson and Martinett (1983:37) state that possessives in English refer to the possessor and not to the thing possessed. Below are some examples of errors in the use of possessives.

(28) He live in indonesia because him parents is a from appliances IndonesianNetherlands (POSS22-1)
In this clause, the student uses the objective pronoun him to state the possessiveness of the noun parents. The objective pronoun is not used to denote a noun as someone's belonging. The correct form to denote the noun as one belonging is possessive. Since the noun parent belongs to the subject he, the possessive form that should replaced the objective him is his. Hence, the correction for this noun phrase is his parents.

(29) He live in indonesia because his parents is a from appliances IndonesianNetherlands

\subsection{Quantifiers}

Quantifiers are a kind of determiner which denotes the quantity of the noun. Leech and Startvik (1981:48) regard quantifiers as amount words which tell the amount of the noun. Below are some examples of errors in the use quantifiers.

(30) Washing machine helps us to wash our clothes. It isn't waste our energy and it is very helpful in each home (QUAN21-5)

The use of determiner each in this clause is incorrect. The correct determiner is every. According to Quirk and Greenbaum (1973:110) each refers to individuals that are already specified. However, the noun home that follows the determiner each does not have reference to any specific home. Therefore, the determiner every should be used to replace it.

(31) Washing machine helps us to wash our clothes. It isn't waste our energy and it is very helpful in every home (QUAN21-5) 
2. Errors according to the Structural Alteration of the Determiners

The wrong use of determiners that were made by the students of English Department causes some structural alteration of the determiners. There are five stuructural alterations of determiners. There are addition, omission, misorder, misformation, and misuse.

\subsection{Addition}

Addition errors are a kind of errors that results from the addition of unnecessary elements. In this case, the according to Dulay et al. (1982: 150) an addition error is characterized by the presence of an item that must not appear in a correct sentence or utterance. Below are some of the examples of errors caused by the addition of determiners.

(32) These performance in competition football at AFF Suzuki Cup 2010 is a greats and excited (ART22-4)

In (32) there is the indefinite article a that precedes the adjective great. A determiner is a function word that modify a noun. Leech and Startvik (1981:225) mention that determiners are words which specify the range of reference of a noun in various ways. The indefinite article here must not be used since there is no noun to modify. Therefore, the indefinite article $a$ in (40) should be removed.

(33) These performance in competition football at AFF Suzuki Cup 2010 is great and excited

\subsection{Omission}

An omission error, according to Dulay et al. (1982: 150) occurs when there is an omission of an item that must appear in a correct sentence or utterance. Here are some examples of error caused by the omission of determiners and.

(34) For many purposes in their life such as dishwasher, a vacum cleaner, etc to help people to do households (ART12-1)

In this clause there is an omission of the indefinite article $a$. The article a should be used here since the noun dishwasher is an indefinite singular countable noun. Therefore, the correction for the clause above is

(35) For many purposes in their life such as a dishwasher, a vacum cleaner, etc to help people to do house holds

There are 29 of errors caused by omisson. All the omission error are articles both the definite and the indefinite one. It can be concluded that the English Literature Students year 2011 do not understand fully the function of the articles since many student omit the article when the article should be appear.

\subsection{Misordering}

A misordering error is an error that is caused by the wrong order of the words in sentence or utterance. According to Dulay et al. (1982: 150) misordering happens when there is a wrong order of a morpheme in a sentence or utterance. Below are some examples of errors caused by the misordering of determiners

(36) I am is the one of fans Irfan Bachdim (ART05-2)

The order of the definite article the which the respondent put before one indicates that the respondent is the only one that adore Ir- 
fan Bachdim, while the sentence tends to say that the respondent is one of Irfan Bachdim fans along with others admirer. Therefore, the noun phrase should be one of the Irfan Bachdim fans.

(37) I am one of the Irfan Bachdim fans (ART05-2)

\subsection{Misformation}

A misformation error, according to Dulay is caused by the usage of wrong forms of the structures. Here are some examples of errors in the misformation of determiners.

(38) I feel optimistic to get a best score in all exams (ART03-2)

In (38) there is an error caused by the misformation the articles $a$. The indefinite article $a$ in the noun phrase a best score is wrongly used. It is erronous since the article that is used in the superlatives is the definite article the. Hence, the indefinite article a should be changed into the definite article the. the noun phrases should be read the best score. The correct version is

(39) I feel optimistic to get the best score in all exams

Below is a misformation of the demonstratives.

(40) In this facilities, they gives our lives more easy to make connection with other people in the world (DEM01-1)

In (40) there is a misformation of demonstratives in the noun phrase this facilities. Eventhough, the verb gives in (40) indicates a verb for singular subject, the pronoun they, which is plural, refers to the noun facilities, supports the evidence that the noun facilities is plural. Hence, the demonstrative this should be also changed into plural form. The plural form of this is these. The correction for this clause is

(56)In these facilities, they gives our lives more easy to make connection with other people in the world

\subsection{Misuse}

Misuse is the terms of an error caused by the misuse of the determiner. The determiner should be modifying a noun. However, this error consists of the determiner that is used within another part of speech that is not a noun and the use of the determiners that is not agree with the character of the determiners. Below are the examples of the errors caused by misuse of the determiner and the explanation.

(61) This disease makes the people can't feel the sad, afraid, and sympathy so they kill the people without feeling (ART18-3)

A determiner is a function word that accompany noun. However, the determiner the that is used by the respondents is preceding the adjective sad and afraid. Therefore, the adjective should be changed into noun sadness. The correct version is

(62) This disease makes the people can't feel the sadness, afraidness, and sympathy so they kill the people without feeling

\section{CONCLUSION}

Several conclusions can be drawn from the analysis on the incorrect uses of determiners that were made by first year stu- 
dents of the English Department, Faculty of Cultural Sciences Gadjah Mada University. Most of the errors were articles with 71 cases $(72.44 \%)$, followed by possessives with 12 cases (12.24\%), demonstratives with 10 cases $(10.20 \%)$, and quantifiers with 5 cases $(5.10 \%)$. The results suggest that the students had a major difficulty in the use of articles in writing in English. They did not seem to have difficulty in the use of demonstratives, possessives, and quantifiers. However, 42 $(59.15 \%)$ of the errors were related with the use of the definite article and 29 (40.84\%) errors were related with the use of the indefinite article. It can be assumed that the students of the English Department have difficulty in the use of articles in general and the definite article in particular.

The incorrect use of determiners that were made by the students of the English Department led to some structural alterations of the determiners. There are five sturctural alterations in determiner, i.e. omission with 29 cases $(29.59 \%)$, , followed by misformation with 28 cases $(28.57 \%)$, addition with 19 cases $(19.38 \%)$, misuse with 14 cases $(14.28 \%)$, and misordering with 8 cases $(8.16 \%)$. It can be seen that most of the structural alteration the students made is the omission. However, all of the determiner that the students omitted are in the form of article. Therefore it can be suggested that most of the students tend to omit the articles in their writing.

The results of this research somehow reflect the ability of most Indonesian students in the use of determiners. The data were taken from the English Department Students, Gadjah Mada Univeristy, one of the top universities in Indonesia. However, a continuation re- search on the same topic is suggested, since this research has a very limited data and a very limited scope of study. The researcher hopes that this research will be an initial research for this topic. There are many other point of views or aspects that can be studied, for instance, the cause of the Indonesian students' errors in the use of determiners, and etc.

Hopefully this research can be used as a reference for the teacher to know the ability of the students in the use of determiner and for the teacher to emphasize and to pay attention more on the determiner use in the students' writing and speaking.

\section{BIBLIOGRAPHY}

Atkinson, Radford, and friends. 2002. Linguistics: An Introduction. Cambridge: University Press.

Ba'dulu, Abdul Muis. 2008. English Syntax. Makassar: badan penerbit Universitas Makassar

Brown, H. Douglas. 2000. Principles of Language Learning and Teaching. New York: Pearson Education Company

Dulay, et al. 1982. Language Two. Oxford:Oxford University Press

Grace, Eudia and Th. M. Sudartwati. 2006. Look Ahead 3. Jakarta: Erlangga.

Haryanto, Toni. 2008. Grammatical Error Analysis in Students' Recount Text. Semarang: Universitas Negeri Semarang. Unpublished Undergraduate Graduating Paper.

Hornby, A.S. 1982. A Guide to Patterns and Usage in English. Oxford: Oxford University Press.

Huddleston, Rodney. 1989. Introduction to the Grammar of English. Cambridge: Cambridge University Press.

Ingketria, Enny. 2007. Error Analysis on Subject Verb and Wrong Repetition: A Case Study on TOEFL Test of 2006. Yogyakarta: UGM. Unpublished Undergraduating Paper.

Kardimin, Akhmad. 2009. Fundamental English Grammar. Yogyakarta; Pustaka Pelajar. 
Kristiningsih, Veri. 2007. Verbal Error Analysis on the TOEFL Test: A Case Study of the New Students of Gadjah Mada University. Yogyakarta: UGM. Unpublished Undergraduating Paper.

Leech, Geoffrey and Startvik. 1981. A Communicative Grammar of English. Essex: Longman

Miller, Jim. 2002. Introduction to English Syntax. Edinburgh: Edinburgh University Press.

Morley, G. David. 2000. Syntax in Functional Grammar. London: Continuum.

Muhtadi, Maftuh. 2008. Error Analysis on The Use of Pronouns: Case Study on the TOEFL-Like Test of the New Students of Gadjah Mada University. Yogyakarta: UGM. Unpublished Undergraduating Paper.

Murphy, Raymond. 1992. Essential Grammar in Use. Cambridge: Cambridge University Press.

Murphy, Raymond. 1997. Essential Grammar in Use. Cambridge: Cambridge University Press.
Ningtyas, Liza. 2007. A Study in Adjective and Noun Clause: An Error Analysis on the TOEFL-Test of Students of 2006 of Gadjah mada University. Yogyakarta: UGM. Unpublished Undergraduating Paper.

Quirk, Randolph and Sidney Greenbaum. 1973. A University Grammar of English. Essex: Longman

Radford, Andrew. 1997. Syntax-A Minimalist Introduction. Harlow, Essex: Department of Language and Linguistic

Savitri, Dewi Indrayati. 2008. An Error Analysis of the Use of Parts of Speech in English Job Vacancy Advertisements. Yogyakarta: UGM. Unpublished Undergraduating Paper.

Suryati, Chatarina. 2010. An Analysis Errors in Compositions Made by First Year Students of the Faculty of Cultural Science Universitas Gadjah Mada 2009/2010. Yogyakarta: UGM. Unpublished Undergraduating Paper.

Thompson, A.J and V.H Martinett. 1983. A Practical English Grammar. Oxford: Oxford University Press. 